\title{
Radiology of uncomplicated asthma
}

\author{
MARGARET E. HODSON, G. SIMON, \\ a n d J.C. B A T T E N \\ Brompton Hospital, London
}

\begin{abstract}
Hodson, Margaret E., Simon, G., and Batten, J. C. (1974). Thorax, 29, 296-303. Radiology of uncomplicated asthma. In 22 of the 117 patients with asthma, over 15 years of age, the chest radiograph showed overinflation $\left(\mathrm{O}_{1}\right.$ pattern $)$ and additional vascular changes in two $\left(\mathrm{O}_{2}\right.$ pattern). Neither abnormality was seen in 60 controls. Abnormal radiographs were found in $31 \%$ of patients whose asthma started before the age of 15 but in none of those in whom it started over 30 years of age. The mean age of patients with abnormal radiographs was 24.6 years, compared with 40.1 years for those with normal films. Radiographic changes bore no relation to duration of disease. In some cases the abnormality persisted; in others it was present only during the acute episode.
\end{abstract}

The appearances of the chest radiograph in children with asthma have recently been described (Simon, Connolly, Littlejohns, and McAllen, 1973). The aim of the present study is to determine the incidence of abnormal chest radiographs in patients over the age of 15 with asthma. Those with radiological shadowing of a localized nature have been excluded, e.g., pneumonia and allergic aspergillosis.

\section{PATIENTS}

We studied the chest radiographs of 117 patients admitted to Brompton Hospital with a clinical diagnosis of asthma. All patients had tests of ventilatory function performed and only those showing at least $25 \%$ variability between the highest and lowest recorded forced expiratory volume in one second $\left(\mathrm{FEV}_{1}\right)$ or peak expiratory flow rate (PEFR) were included. All these patients used daily bronchodilator drugs in order to lead a normal life and most were on long-term disodium cromoglycate, corticosteroids or ACTH.

The controls were fit members of the hospital staff, ranging in age from 15 to 65 years, and free from respiratory symptoms.

\section{METHODS}

Each patient had an FEV 1 or PEFR performed on the day of the chest radiograph in this study and relevant clinical details were recorded at the same time. The severity of asthma on the day of the radiograph was expressed as:

$$
\frac{\text { PEFR or FEV }}{\text { Predicted PEFR or FEV }_{1}} \times 100
$$

The best of three readings was taken on each occasion.

All the chest radiographs were reported by the same observer (G.S.) who at the time was unaware whether he was reporting the films of an asthmatic or a normal control.

RADIOGRAPHIC TECHNIQUE Each patient had a standard postero-anterior film taken at $6 \mathrm{ft}(1.8 \mathrm{~m})$ during suspended inspiration. About half the patients also had a lateral view taken.

RADIOLOGICAL ANALYSIS Measurements of diaphragm level (Lennon and Simon, 1965), lung $N$ length, lung width, and heart width were recorded. For those with a lateral film the size of the retrosternal transradiant zone was also measured. The $\omega$ size of the hilar vessels relative to the peripheral lung vessels was recorded.

The diaphragm level was taken as the height of the top of the right dome of the diaphragm in + the mid-lung field in relation to the inferior angle $\frac{T}{\vec{O}}$ of the anterior ribs. Lung length was estimated $\frac{P}{\mathbb{D}}$ by drawing a horizontal line at the level of the $\stackrel{+}{\oplus}$

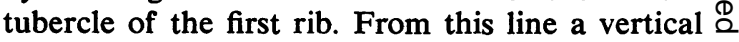
line was drawn to the top of the dome of the right diaphragm in the mid-lung field. Lung width was 
measured by drawing a horizontal line at the level of the right dome of the diaphragm to the internal aspect of the ribs on each side. The transverse diameter of the heart was measured as the furthest projections of the heart to the right and to the left of the mid-line added together. These measurements were performed in the manner described by Simon et al. (1972) (Fig. 1).

The size of the retrosternal transradiant area was measured as the distance from a point $3 \mathrm{~cm}$ below the angle of the sternum to the aorta (Simon, 1971).

The ratio of the size of the hilar vessels to that of the intrapulmonary vessels was recorded. This was a subjective comparison of the relative sizes of the vessels.

INTERPRETATION OF THE RADIOLOGICAL APPEARANCES The radiographs were classified into three groups:

(A) Normal pattern Presenting the following features:
1. diaphragm at or above the anterior rib level of $6 \frac{1}{2}$;

2. lung width greater than lung length;

3. heart diameter $11.5 \mathrm{~cm}$ or over;

4. if lateral film available, retrosternal transradiant area under $3.5 \mathrm{~cm}$;

5 . vessel pattern normal.

(B) $O_{1}$ pattern (Fig. 2a) Simple overinflation presenting two or more of the following abnormalities:

1. diaphragm below anterior rib level of $6 \frac{1}{2}$;

2. lung length the same or greater than lung width;

3. heart diameter less than $11.5 \mathrm{~cm}$;

4. retrosternal transradiancy greater than $3.5 \mathrm{~cm}$.

(C) $\mathrm{O}_{2}$ pattern (Fig. 3a) Complicated overinflation similar to the $O_{1}$ pattern but, in addition, the hilar vessels are relatively large compared with the lung vessels. The change in the lung vessels is uniform (Simon et al., 1973).

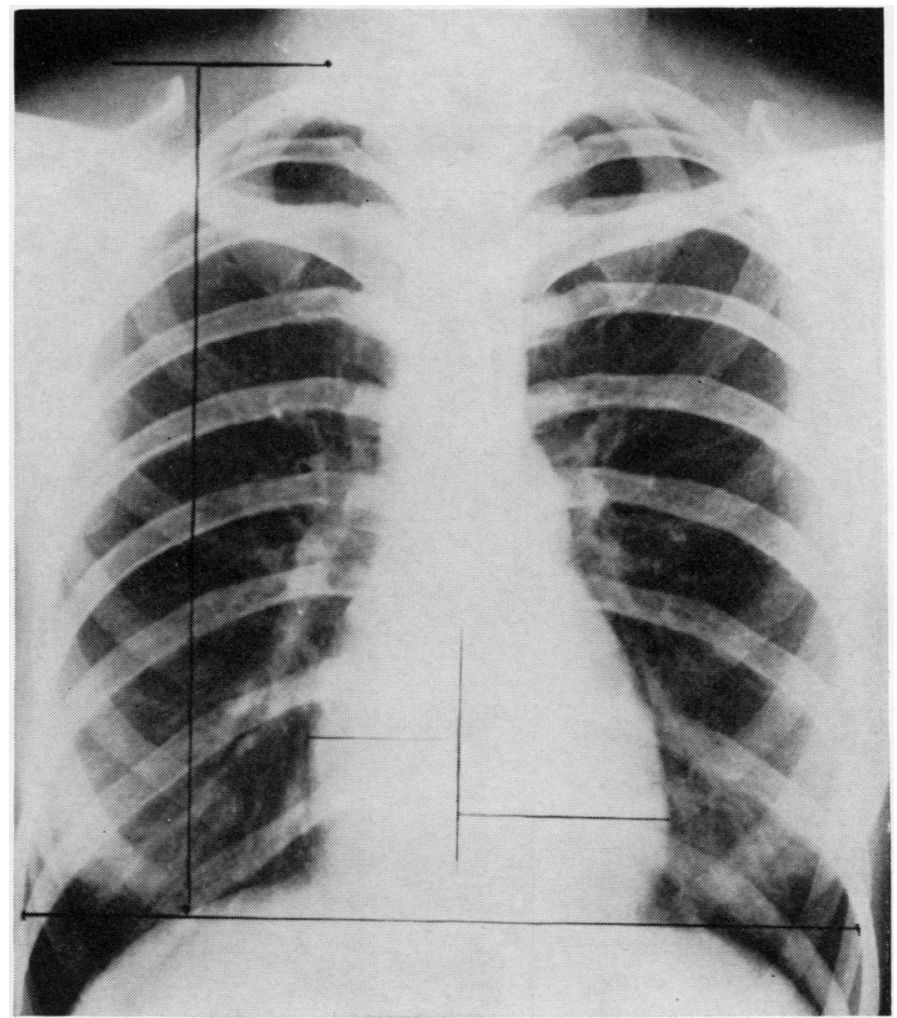

FIG. 1. Normal radiograph showing method of measuring lung width, lung length, and transverse heart diameter. 


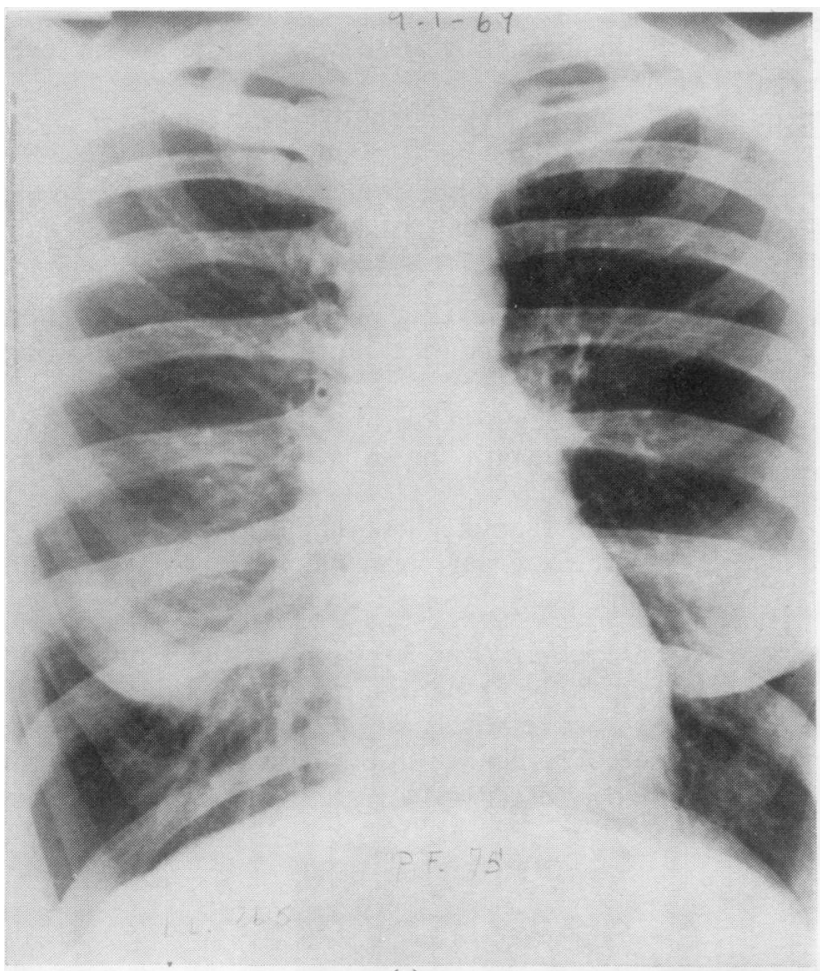

(a)

FIG. 2. Woman aged 25 years. Asthma onset aged 2 years. (a) PEFR $75 \mathrm{l} / \mathrm{min}$. $O_{1}$ pattern. Diaphragm at 7 th rib. Heart diameter $9.5 \mathrm{~cm}$. Lung length $26.5 \mathrm{~cm}$. Lung width $25 \mathrm{~cm}$. Hilar vessels normal. (b) PEFR $260 \mathrm{l} / \mathrm{min}$. $O_{1}$ pattern remains. Diaphragm at 7 th rib. Heart diameter $9.5 \mathrm{~cm}$. Lung length $27 \mathrm{~cm}$. Lung width $25 \mathrm{~cm}$. Hilar and lung vessels normal.

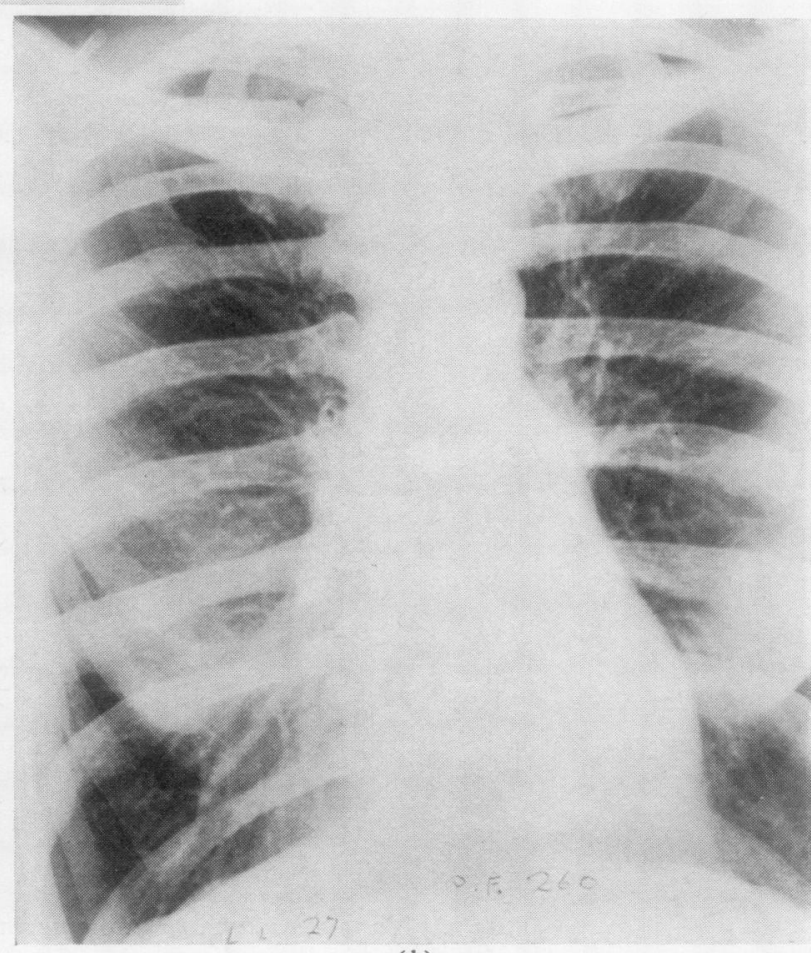

(b) 


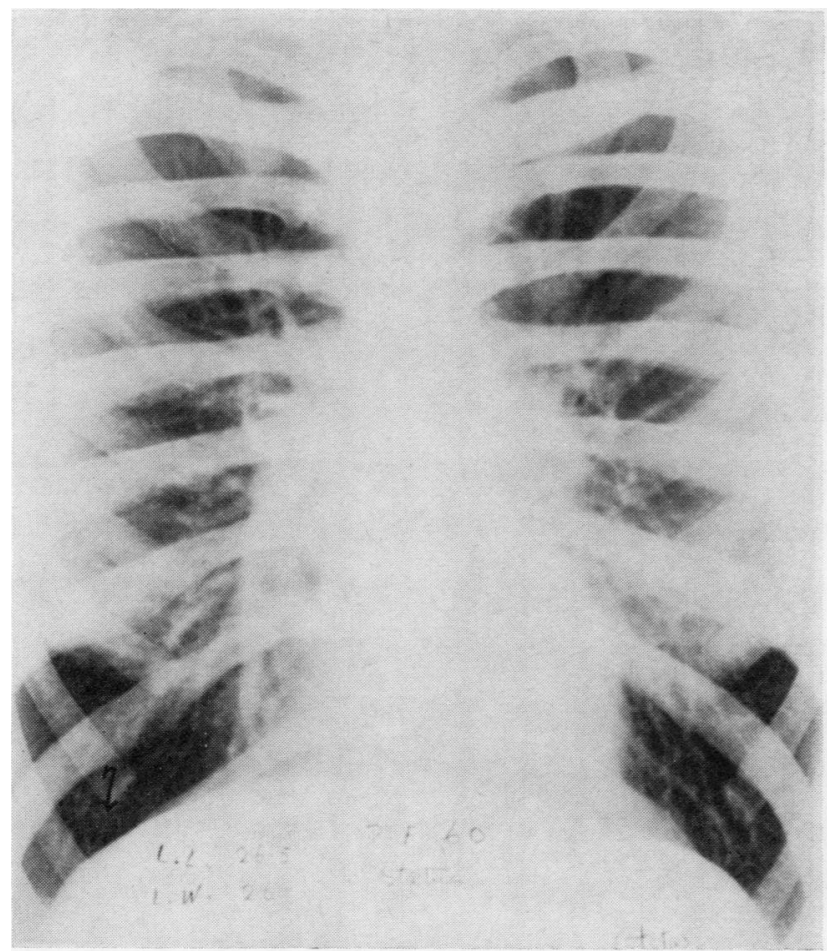

(a)

FIG. 3. Girl aged 18 years. Asthma onset aged 2 years. (a) PEFR $60 \mathrm{l} / \mathrm{min}$. Shows $\mathrm{O}_{2}$ complicated overinflation. Diaphragm below 7th rib. Heart diameter $9 \mathrm{~cm}$. Lung length $26.5 \mathrm{~cm}$. Lung width $26 \mathrm{~cm}$. Basal artery $14 \mathrm{~mm}$. Peripheral vessels relatively small. (b) PEFR $280 \mathrm{l} / \mathrm{min}$. Normal pattern. Diaphragm at $6 \frac{1}{2}$ rib. Heart diameter $12.5 \mathrm{~cm}$. Lung length $22.5 \mathrm{~cm}$. Lung width $28 \mathrm{~cm}$. Hilar and lung vessels normal.

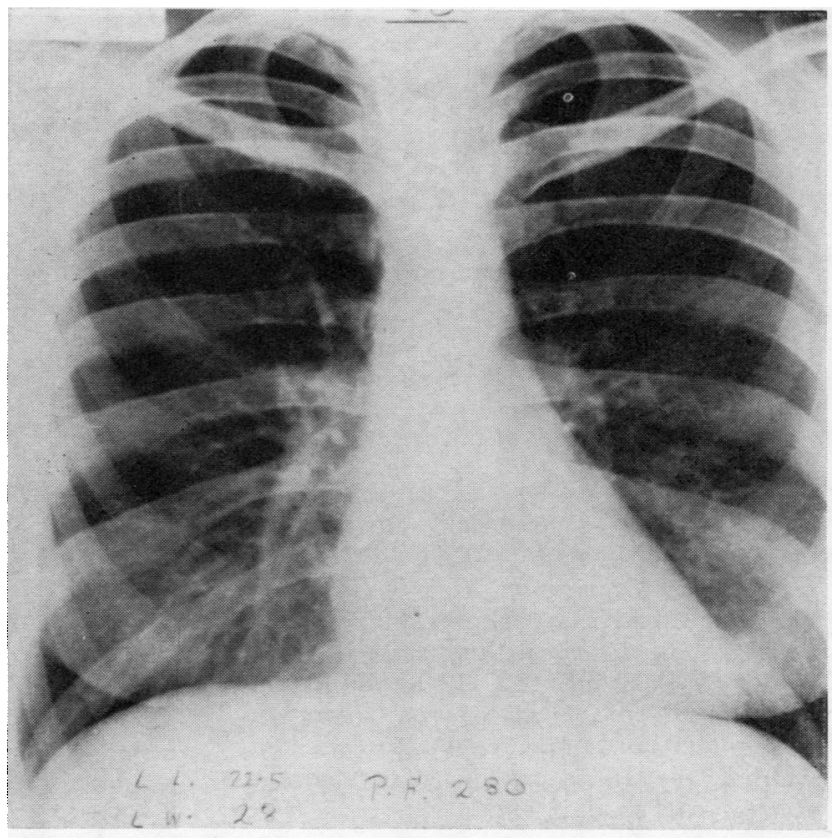

(b) 


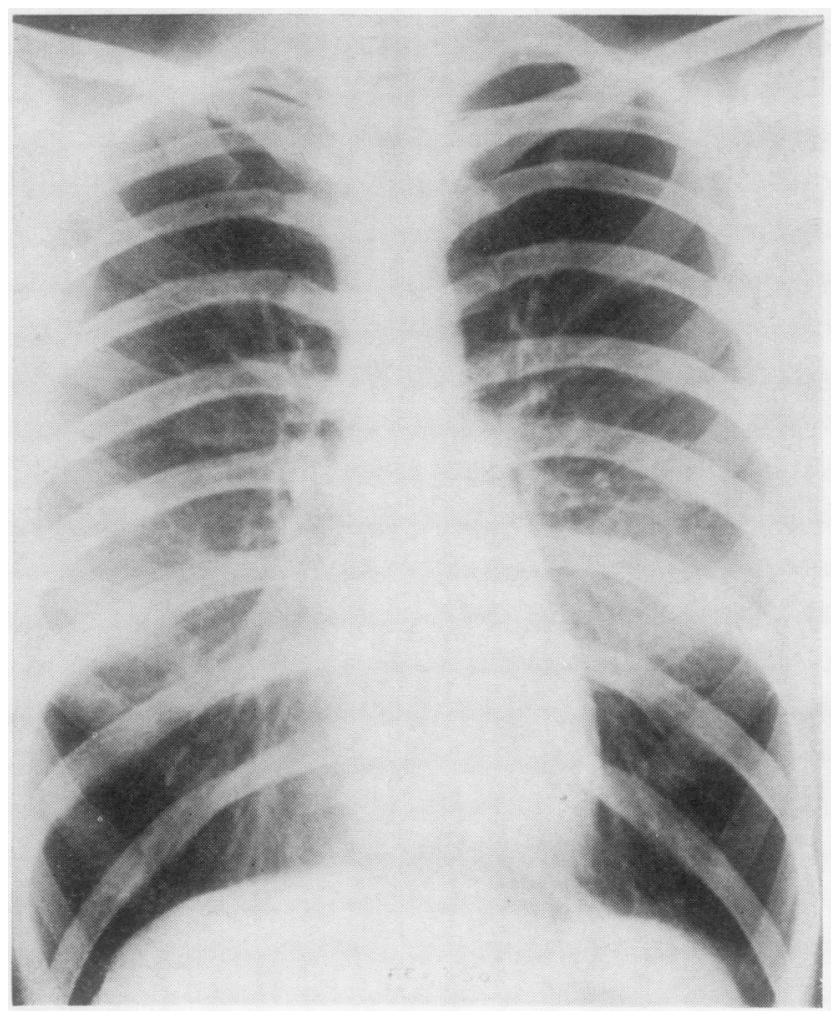

(a)

FIG. 4. Girl aged 18 years. Asthma onset aged 2 years. (a) FEV $450 \mathrm{ml}, \mathrm{FVC} 500 \mathrm{ml}$. $O_{1}$ pattern. Diaphragm at 7 th rib. Heart diameter $8 \mathrm{~cm}$. Lung length $29.5 \mathrm{~cm}$. Lung width $25 \mathrm{~cm}$. Hilar and lung vessels normal. (b) FEV 3,600 ml, FVC 3,800 ml. Normal pattern. Diaphragm at $6 \frac{1}{2}$ rib. Heart diameter $11.5 \mathrm{~cm}$. Lung length $27 \mathrm{~cm}$. Lung width $25 \mathrm{~cm}$. Hilar and lung vessels normal. Retrosternal space $2 \mathrm{~cm}$.

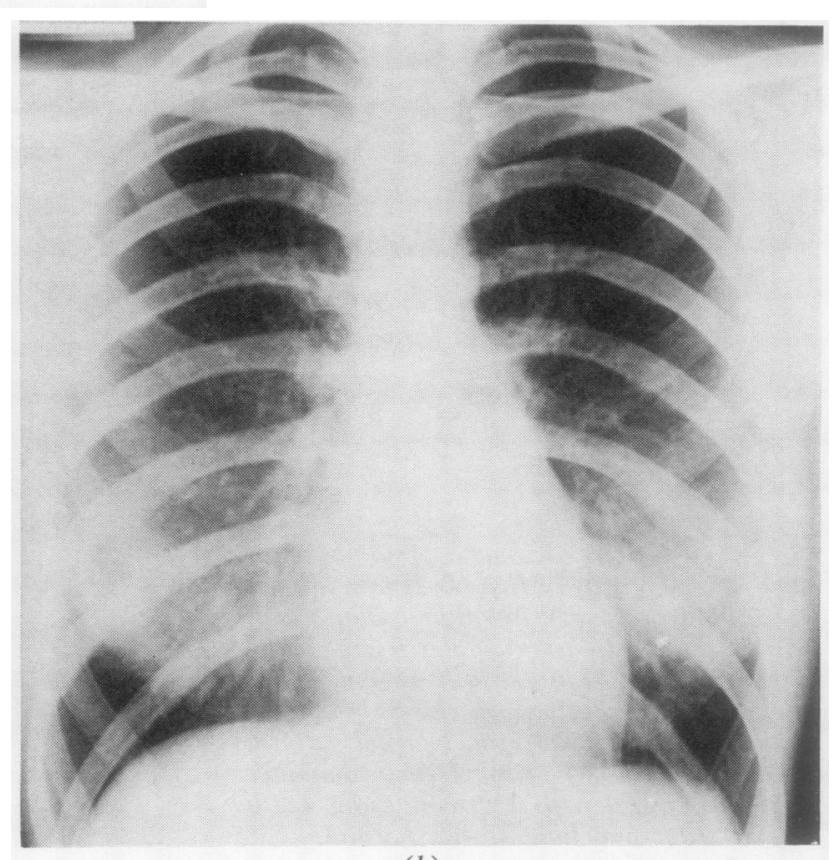


T A B L E I

\begin{tabular}{|c|c|c|c|c|c|}
\hline & \multirow[b]{2}{*}{$\begin{array}{l}\text { No. of } \\
\text { Cases }\end{array}$} & \multicolumn{4}{|c|}{ Patients with } \\
\hline & & $\begin{array}{l}\text { All Normal } \\
\text { Radiographs }\end{array}$ & $\begin{array}{c}\text { Some Abnormal } \\
\text { Radiographs } \\
\mathrm{O}_{1} \text { or } \mathrm{O}_{3}\end{array}$ & $\begin{array}{c}\text { Constantly } \\
\text { Abnormal } \\
\text { Radiographs }\end{array}$ & $\begin{array}{l}\text { Abnormal } \\
\text { Radiographs } \\
\text { only present } \\
\text { in Status }\end{array}$ \\
\hline $\begin{array}{l}\text { Controls } \\
\text { Asthmatics }\end{array}$ & $\begin{array}{r}60 \\
117\end{array}$ & $\begin{array}{l}60 \\
95\end{array}$ & $22 \quad \begin{array}{l}0 \\
(19 \%)\end{array}$ & $14 \stackrel{0}{(12 \%)}$ & $8 \stackrel{0}{(7 \%)}$ \\
\hline
\end{tabular}

Of the 22 abnormal films (Table I), 20 were classified as $\mathrm{O}_{1}$ and two as $\mathrm{O}_{2}$. Some patients had abnormal radiographs when they were in an acute episode and also when they had recovered (Fig. $2 b)$. Seven $O_{1}$ pattern radiographs and one $\mathrm{O}_{2}$ pattern radiograph returned to normal when the acute asthmatic attack was over (Figs. 3b and 4).

These abnormal radiographs were considered in relation to the age of the patient (Table II), age of onset of the asthma (Table III), duration of the disease (Table IV), and severity of the asthma on the day the abnormal radiograph was taken (Table $\mathrm{V}$ ). $\mathrm{O}_{1}$ and $\mathrm{O}_{2}$ radiographs were considered together as the number of $\mathrm{O}_{2}$ cases was so small.

T A B L E I I

AGE AT TIME OF CHEST RADIOGRAPH

\begin{tabular}{|c|c|c|c|c|c|}
\hline \multirow[b]{2}{*}{ Age (yr) } & \multirow{2}{*}{$\begin{array}{l}\text { No. of } \\
\text { Cases }\end{array}$} & \multicolumn{2}{|c|}{$\begin{array}{c}\text { Normal } \\
\text { Radiograph }\end{array}$} & \multicolumn{2}{|c|}{$\begin{array}{c}\text { Abnormal } \\
\text { Radiograph }\end{array}$} \\
\hline & & No. & $\%$ & No. & $\%$ \\
\hline $\begin{array}{c}15-29 \\
30-44 \\
45+\end{array}$ & $\begin{array}{l}44 \\
29 \\
44\end{array}$ & $\begin{array}{l}28 \\
24 \\
43\end{array}$ & $\begin{array}{c}63 \cdot 5 \\
83 \\
98\end{array}$ & $\begin{array}{r}16 \\
5 \\
1\end{array}$ & $\begin{array}{c}36 \cdot 5 \\
17 \\
2\end{array}$ \\
\hline Mean & & \multicolumn{2}{|c|}{$40 \cdot 1$} & \multicolumn{2}{|c|}{$24 \cdot 6$} \\
\hline
\end{tabular}

Statististically significant: $x^{2}=9.3 ; 0.005>p>0.001$.

T A B L E I I I

AGE OF ONSET OF ASTHMA

\begin{tabular}{|c|c|c|c|c|c|}
\hline \multirow[b]{2}{*}{ Age (yr) } & \multirow{2}{*}{$\begin{array}{l}\text { No. of } \\
\text { Cases }\end{array}$} & \multicolumn{2}{|c|}{$\begin{array}{c}\text { Normal } \\
\text { Radiograph }\end{array}$} & \multicolumn{2}{|c|}{$\begin{array}{c}\text { Abnormal } \\
\text { Radiograph }\end{array}$} \\
\hline & & No. & $\%$ & No. & $\%$ \\
\hline $\begin{array}{c}0-14 \\
15-29 \\
30+\end{array}$ & $\begin{array}{l}58 \\
25 \\
34\end{array}$ & $\begin{array}{l}40 \\
21 \\
34\end{array}$ & $\begin{array}{r}69 \\
84 \\
100\end{array}$ & $\begin{array}{r}18 \\
4 \\
0\end{array}$ & $\begin{array}{r}31 \\
16 \\
0\end{array}$ \\
\hline Mean & & \multicolumn{2}{|c|}{$22 \cdot 4$} & \multicolumn{2}{|c|}{7.4} \\
\hline
\end{tabular}

Statistically significant: $\chi^{2}=9 \cdot 06 ; 0.005>P>0.001$.

T A B L E I V

DURATION OF DISEASE

\begin{tabular}{|c|c|c|c|c|c|}
\hline \multirow{2}{*}{$\begin{array}{c}\text { Duration } \\
\text { (yr) }\end{array}$} & \multirow{2}{*}{$\begin{array}{l}\text { No. of } \\
\text { Cases }\end{array}$} & \multicolumn{2}{|c|}{$\begin{array}{c}\text { Normal } \\
\text { Radiograph }\end{array}$} & \multicolumn{2}{|c|}{$\begin{array}{c}\text { Abnormal } \\
\text { Radiograph }\end{array}$} \\
\hline & & No. & $\%$ & No. & $\%$ \\
\hline $\begin{array}{c}0-14 \\
15-29 \\
30+\end{array}$ & $\begin{array}{l}45 \\
54 \\
18\end{array}$ & $\begin{array}{l}40 \\
37 \\
18\end{array}$ & $\begin{array}{r}89 \\
68 \\
100\end{array}$ & $\begin{array}{r}5 \\
17 \\
0\end{array}$ & $\begin{array}{r}11 \\
31 \cdot 5 \\
0\end{array}$ \\
\hline Mean & & \multicolumn{2}{|c|}{$18 \cdot 2$} & \multicolumn{2}{|c|}{$19 \cdot 0$} \\
\hline
\end{tabular}

There is no significant difference between the patients with abnormal and those with normal radiographs in respect to duration of disease (Table IV).

T A B L E V

SEVERITY OF ASTHMA AT TIME OF CHEST RADIOGRAPH

\begin{tabular}{|c|c|c|c|c|c|}
\hline \multirow{2}{*}{$\begin{array}{l}\text { Ventilatory Function } \\
\% \text { predicted PEFR or } \\
\text { FEV }\end{array}$} & \multirow{2}{*}{$\begin{array}{l}\text { No. of } \\
\text { Cases }\end{array}$} & \multicolumn{2}{|c|}{$\underset{\text { Radiograph }}{\text { Normal }}$} & \multicolumn{2}{|c|}{$\begin{array}{c}\text { Abnormal } \\
\text { Radiograph }\end{array}$} \\
\hline & & No. & $\%$ & No. & $\%$ \\
\hline $\begin{array}{l}0-32 \\
33-66 \\
67-100\end{array}$ & $\begin{array}{l}42 \\
48 \\
27\end{array}$ & $\begin{array}{l}31 \\
39 \\
25\end{array}$ & $\begin{array}{l}74 \\
81 \\
93\end{array}$ & $\begin{array}{r}11 \\
9 \\
2\end{array}$ & $\begin{array}{r}26 \\
19 \\
7\end{array}$ \\
\hline Mean & & \multicolumn{2}{|c|}{49.6} & \multicolumn{2}{|c|}{37.9} \\
\hline
\end{tabular}

$x^{2}$ trend $=3 \cdot 73 ; \mathrm{P}>0.05$.

The difference in ventilatory function between the patients with abnormal and those with normal radiographs did not quite attain statistical significance at the $5 \%$ level (Table V).

\section{DISCUSSION}

Of 44 adult asthmatics aged 15-29 years 36.5\% had abnormal chest radiographs. The abnormalities appear to be related to the age of onset of asthma but not to its duration. Thirty-one per cent of adults with onset between 0 and 14 years had abnormal radiographs but we could find no abnormal radiographs among patients whose asthma began after the age of 30 . As asthmatics get older they are less liable to show this abnormal radiographic appearance (see Table II and Fig. 5).

In a recent paper (Simon et al., 1973) it was shown that $27 \%$ of 218 asthmatic children had abnormal chest radiographs: $15 \%$ showed the $O_{1}$ pattern and $12 \%$ the $\mathrm{O}_{2}$ pattern. In the present study we found $31 \%$ abnormal radiographs among adults whose asthma began before the age of 15 . This resembles the incidence in children but the $\mathrm{O}_{2}$ pattern is much less common in young adults than in children and both our $\mathrm{O}_{2}$ radiographs were of patients with onset before 15 years.

Radiographic appearances of patients with emphysema (Reid and Millard, 1964; Simon, 1964, 1970) and primary pulmonary hypertension 


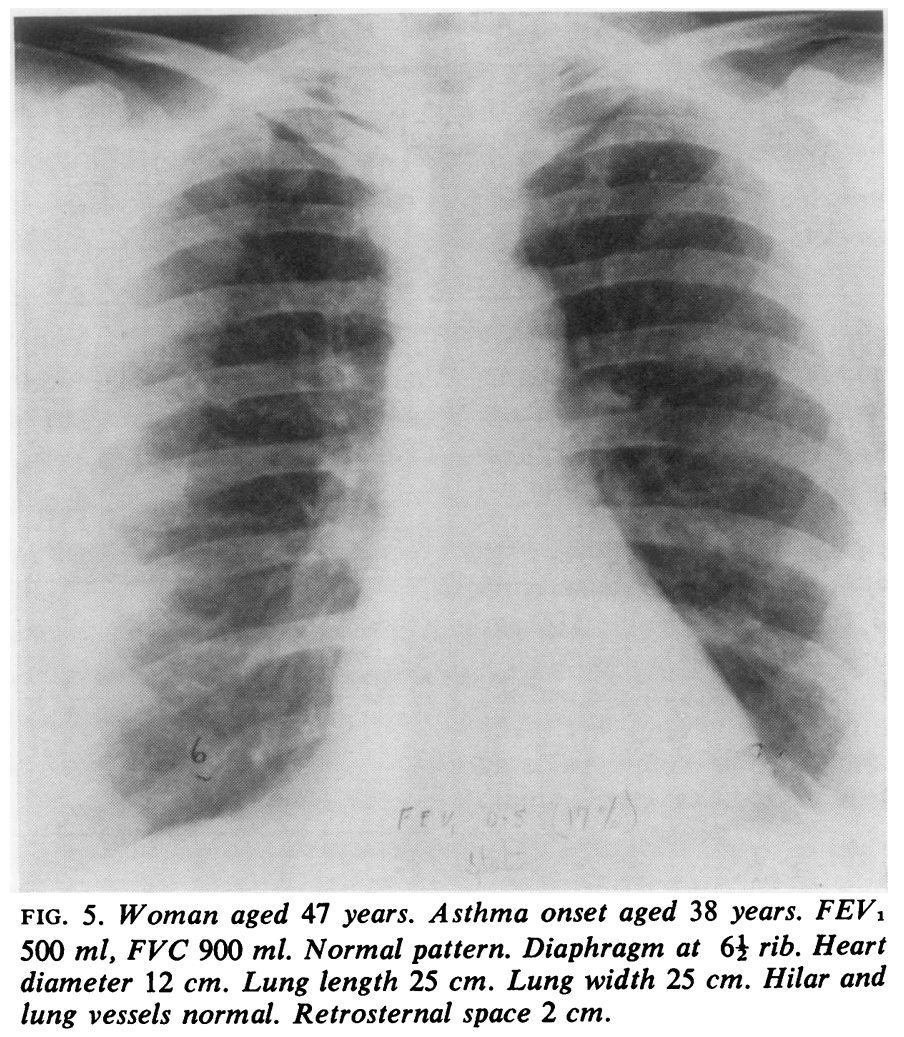

(Anderson, Reid, and Simon, 1973) may be confused with the appearances we have described here in asthmatics with an early age of onset.

Radiographs of patients with severe widespread panacinar emphysema often show a low flat diaphragm, a large retrosternal transradiant area, and a narrow vertical heart together with small lung vessels in some areas and normal or large vessels in other areas. In the asthmatics with $\mathrm{O}_{2}$ radiographs, the vascular pattern is different in that vascular changes are uniform throughout the lungs at equal distance from the hilum.

Chest radiographs of patients with primary pulmonary hypertension show a large pulmonary artery and hilar vessels while the lung vessels appear relatively small but there is no evidence of air-trapping, so the diaphragm will appear normal and the heart shadow enlarged rather than narrow and vertical.

We conclude that there are specific radiological changes present in a proportion of asthmatics. In some, these changes are present only during the acute episode, and in others they are a constant feature. These changes appear to be related to the age of onset of the asthma and are found less frequently as the patient gets older. The reason for the radiological appearances is uncertain.

We are grateful to the physicians at the Brompton Hospital who allowed us to study their patients. We should like to thank Mrs. Ruth Tall for help with the statistics, Miss Lillian Topping for secretarial assistance, and Mr. J. Collier of the Medical Records Department.

\section{REFERENCES}

Anderson, G., Reid, L., and Simon, G. (1973). The radiographic appearances in primary and thromboembolic pulmonary hypertension. Clinical Radiology, 24, 113.

Lennon, E. A. and Simon, G. (1965). The height of the diaphragm in the chest radiograph of normal adults. British Journal of Radiology, 38, 937.

Reid, L. and Millard, F. J. C. (1964). Correlation between radiological diagnosis and structural lung changes in emphysema. Clinical Radiology, 15, 307.

Simon, G. (1964). Radiology and emphysema. Clinical Radiology, 15, 293. 
(1970). Radiology and chronic airways obstruction. In: Modern Trends in Diagnostic Radiology, edited by J. W. McLaren, vol. 4, chap. 2, p. 21. Butterworths, London.

(1971). Principles of Chest x-ray Diagnosis. The Retrosternal Transradiant Zone, 3rd edition, p. 29. Butterworths, London.

Connolly, N., Littlejohns, D. W., and McAllen, M. (1973). Radiological abnormalities in children with asthma and their relation to the clinical findings and some respiratory function tests. Thorax, 28, 115.

Reid, L., Tanner, J. M., Goldstein, H., and Benjamin, B. (1972). Growth of radiologically determined heart diameter, lung width, and lung length from 5-19 years, with standards for clinical use. Archives of Diseases in Childhood, 47, 373.

Requests for reprints to: Dr. G. Simon, Brompton Hospital, Fulham Road, London SW3 6HP. 